\title{
FEMINISME DALAM PROSA LAMA “TJERITA NJI PAINA" KARANGAN H. KOOMER
}

\author{
Oleh: \\ Laura Andri R.M. \\ Jurusan Sastra Indonesia Fakultas Ilmu Budaya Universitas Diponegoro \\ Jl. Prof. H. Soedarto, SH Tembalang Semarang 50275 \\ E-mail: lauraandrirm@yahoo.co.id
}

\begin{abstract}
"Tjerita Nji Paina" was written during the Dutch Colonial period in Indonesia in 1900. In the work of H. Kommer, "Tjerita Nji Paina" is appeared differently compared to the other writting on gender similar issues at the same era. The author's strong simphaty and compassion to "nyai" destiny has ameliorated the negative image of concubine life system in the Dutch Kolonial era. This literature work has clearly shown the braveness of a Dutch Indies woman in dealing with unfairness she faced in her inferior position. Her consiousness on the existent that she was under pressure of patriarchy superiority power has pushed her to struggle to be equal to men. The aim of this research is to unshield ideas fighting the patriarchy system in the community. Other, it pictured the women's efforts to come out from the negative stereotipe that show them as weak and powerless. This research is conducted using feminist literary criticism approach in descriptive qualitative methods.
\end{abstract}

Keywords: women image, feminism, colonial, concubine, patriarchy.

\section{PENDAHULUAN}

Peristiwa penjajahan selalu membawa permasalahan yang kompleks bagi masyarakat negara jajahannya. Selain terbiasa mengalami penindasan serta hidup yang dikendalikan oleh penjajah, masyarakat cenderung dimarginalkan serta dianggap tidak penting atau tidak berarti. Kondisi ini, mau tidak mau, membentuk sikap “menyerah" dan kepatuhan untuk tunduk pada keinginan penjajah dalam setiap aspek kehidupan. Hingga pada akhirnya rasa ketergantungan yang besar dialami oleh masyarakat pada penjajahnya.

Indonesia merupakan salah satu negara yang pernah mengalami masa penjajahan cukup lama. Sebagai negara bekas jajahan tentu saja banyak persoalan yang menjadi beban bangsa Indonesia. Kondisi sosial masyarakat Indonesia adalah sebuah gambaran riil imbas dari kolonialisme Belanda. Kondisi sosial masyarakat tersebut tercermin juga dalam karya-karya sastra. Salah satu karya sastra yang menggambarkan kondisi masyarakat terjajah adalah “Tjerita Nji Paina”. Cerita iniditulis oleh H. Kommer pada tahun 1900 dan dicetak oleh penerbit terkenal pada masanya, yakni A. Veit \& Co. Sejak terbitnya, cerita ini tidak pernah dimasukkan dalam reportoar panggung. Hal ini disebabkan karena $H$. Kommer dengan “Tjerita Nji Paina”-nya, secara sadar atau tidak, telah melancarkan kecaman tajam terhadap kaum pengusaha gula. Padahal pada masa itu kaum pengusaha gula merupakan tulang punggung Hindia Belanda dalam mendapatkan devisa. Isi cerita karangan Kommer ini memang mengandung nada anti-kolonial dan sosial. Pada perkembangannya, “Tjerita Nji Paina” 
menjadi cerita lisan populer di kalangan orang Belanda di Hindia sampai tahun I920an, tanpa pemah menyebut Kommer. Kemudian oleh Pramoedya Ananta Toer, cerita ini dimuat dalam buku Tempo Doeloe antologi sastra pra-Indonesia yang dikumpulkan bersama dengan karya-karya sastra kolonial lainnya.

“Tjerita Nji Paina” (selanjutnya disingkat TNP) merupakan salah satu contoh prosa lama dengan waktu penceritaan relatif singkat sekitar 15 halaman, memiliki plot tunggal dan merupakan cerita terpendek dari antologi “Tempo Doeloe”. Judul cerita itu sendiri menunjukkan bahwa kultur itu seharusnya "Nyi Painah" seperti lazimnya nama-nama Jawa yang berkembang saat itu (Sumardjo 2004:155). Kommer menceritakan kisahnya dengan tempo tinggi, tanpa banyak bunga kata. Kepadatan kisah tercapai dengan komposisi yang baik dan seimbang. Karya ini dengan jelas memberikan informasi yang hidup tentang penindasan alam penjajahan.

Secara jelas dan rinci TNP memberikan gambaran dan informasi tentang penindasan yang dialami oleh bangsa terjajah. Bagaimana kaum pribumi, yang dalam cerita ini diwakili oleh kaum gula di Jawa, tidak dapat berkutik dan hanya menyerah mengikuti semua aturan penjajah. Eksploitasi pribumi khususnya perempuan terjadi secara besar-besaran dalam kurun waktu yang relatif lama. Briot sebagai tokoh penguasa mewakili kaum kolonial dalam TNP dapat berlaku sewenang-wenang, karena memang ia berkuasa bukan secara pribadi saja, tetapi juga secara struktur sosial mengingat ia adalah bagian dari penguasa Belanda.

Selain menonjolkan masalah ketertindasan dan kesewenang-wenangan, ada hal yang lebih menarik dalam cerita ini. Peran tokoh Paina sebagai perempuan Jawa dengan segala keterbatasannyalah yang justru mampu memperdayai dan mengalahkan Tuan Briot. Ayah Paina, Niti Atmojo, gambaran laki-laki pribumi yang cekatan, pintar, cermat dalam masalah keuangan sekaligus kepala keluarga hanya mampu menyerah dan bersembunyi di balik kekuatan Paina, anak perempuannya. Secara tidak langsung, Niti sengaja menjual Paina untuk membebaskan diri dari hukuman penjara.

\section{METODE}

Objek material dalam penelitian ini adalah gambaran perempuan Hindia Belanda ditinjau dari prosa lama TNP karangan H. Kommer. Sedangkan objek formalnya berisi keberanian perempuan Hindia Belanda menentang ketidakadilan yang disebabkan oleh kedudukannya sebagai golongan inferior. Kesadaran akan adanya kekuatan superior yang menekan, mampu mendorong perempuan berusaha menjadi setara dengan laki-laki serta berguna bagi masyarakat. Secara konkret, penelitian ini bertujuan mengungkap gagasan-gagasan dalam TNP yang berlawanan dengan sistem budaya patriarki yang berkembang, baik masa dulu maupun saat sekarang. Serta dijelaskan pula bagaimana usaha dan aksi perempuan keluar dari stereotip negatif. Hal ini berkaitan dengan adanya penilaian yang dimunculkan oleh budaya patriarki, bahwa perempuan adalah mahluk lemah tanpa kekuatan atau otoritas apapun.Perempuan tersubordinasi, kedudukannya di masyarakat lebih rendah daripada laki-laki.

Sehubungan dengan hal di atas, maka teori yang paling tepat digunakan dalam penelitian ini adalah FLC (Feminist Literary Criticism) atau kritik sastra feminis. Pengaplikasian teori tersebut memiliki manfaat penting berkaitan dengan upaya perempuan Hindia Belanda mendapatkan otoritas atas dirinya melalui perspektif sastra. Sementara itu, metode yang dipakai adalah metode deskriptif kualitatif. Penelitian kualitatif adalah penelitian yang bermaksud untuk memahami fenomena tentang apa yang dialami oleh subjek penelitian misalnya perilaku, persepsi, motivasi, tindakan, dan lain-lain secara 
holistik, dan dengan cara deskripsi dalam bentuk kata-kata dan bahasa (Moleong, 2007: 6).

\section{PEMBAHASAN}

Pada umumnya, karya sastra yang menampilkan perempuan dalam karyanya bisa dikaji dari segi feministik. Asal ada tokoh perempuan dalam cerita, entah itu berperan sebagai tokoh utama atau tokoh bawahan, protagonis ataupun antagonis maka pendekatan feministik dapat digunakan untuk menganalisis karya tersebut. Namun demikian, pendekatan ini akan lebih mudah digunakan jika tokoh perempuan itu dikaitkan dengan tokoh lakilaki yang ada dalam karya sastra itu (Djajanegara, 2000:51). Tidak dapat dipungkiri bahwa saat ini penelitian dengan menggunakan pisau analisis berupa kritik sastra feminis telah banyak diminati di Indonesia. Hal ini merepresentasikan adanya kesadaran bahwa fenomena keperempuanan dalam karya sastra harus diungkap dan dijelaskan kepada masyarakat.

Feminisme atau sering disebut kritik sastra feminis merupakan pendekatan yang menitikberatkan pada persoalan perempuan, yaitu melihat sesuatu dari sudut pandang perempuan. Sebab, apapun yang ada dalam kenyataan maupun dalam karya sastra selalu dilihat dari sudut laki-laki, sedang posisi perempuan hanya muncul ketika kaum lakilaki itu berinteraksi dengan kaum perempuan. Posisi perempuan selalu ditempatkan sebagai objek bukan sebagai subjek sehingga perempuan pun selalu diposisikan sebagai mahluk inferior dan laki-lakilah yang menjadi superiornya (Selden, 1993: 135 - 155). Mengingat TNP mengangkat persoalan perempuan Hindia Belanda yang terhegemoni laki-laki maka pendekatan ini sangat signifikan untuk menganalisis cerita tersebut.

\section{Sekilas tentang TNP}

Dikisahkan bahwa Juru tulis Niti Atmojo, ayah dari Nyi Paina adalah karyawan keuangan di sebuah pabrik gula terbesar di Jawa Timur. Kehidupan Niti dan keluarganya amat kecukupan karena gaji yang diterima cukup besar. Hingga akhirnya Niti harus rela menyerahkan anak perempuannya, Paina, menjadi Nyai bagi atasannya yaitu Tuan Briot, seorang kebangsaan Belanda dengan muka buruk dan perangai yang tidak baik. Tuan Briot berhasil memperdayai Niti dengan menjaminkan Paina sebagai ganti dari uang perusahaan yang dihilangkan. Berbekal kecerdasannya, Paina mampu keluar dari pelukan Briot dengan menularkan penyakit cacar pada laki-laki yang mengambil ia menjadi gundiknya. Cerita ini berakhir dengan happy ending, Briot mati karena penyakit cacar sementara Paina hidup bahagia dengan suami dan keluarganya meski wajahnya rusak akibat cacar.

TNP karangan $\mathrm{H}$. Kommer yang terbit tahun 1900 ini digolongkan dalam ragam 'cerita desa' selain 2 karyanya yang lain, yaitu: Tjerita Nji Sarikem dan Tjerita Siti Aisah. Penggolongan dalam cerita desa ini sebabkan karena TNP menuturkan kisah yang mengidealisasikan kehidupan masyarakat pedesaan yang terletak di tengah-tengah alam raya sebagai kehidupan yang penuh dengan harmoni, dengan cinta yang suci, tetapi kemudian dirusakkan oleh persentuhan dari manusia-manusia yang hidup di dalamnya dengan kehidupan masyarakat kota (Faruk, 2007: 261-263).

\footnotetext{
"Sabermoela di tjeritaken, adalah satoe roemah ketjil di desa Poerwo di tanah Djawa Wetan, poenjanja saorang Djawa, bernama Niti Atmodjo, djoeroetoelis fabriek goela, dan roemah itoe ada terdiri di bawah satoe boekit, iang adanja di pinggir kali, iang tiada dalam airnja. Di roemah itoe, Niti tinggal sama istri dan anak-anaknya, laki-laki dan prampoean.” (Toer, 2003: 377).

"Tetapi Niti ampoenja bintang iang amat terang tjahajanja nanti dengan sigrah djoega mendjadi gelap. Bahoea di fabriek
} 
itoe di bikin perobahan besar.” (Toer, 2003:378).

"Itoe koetika moesim panas soedah dateng. Angin barat dari goenoenggoenoeng moelai dateng, bersama-sama penjakit roepa-roepa, serta kebon-kebon teboe semoea moelai djadi kering.” (Toer, 2003: 384).

Kehidupan pedesaan mewakili kondisi masyarakat tradisional Indonesia atau kaum pribumi dengan limpahan kekayaan alam hasil rempah didalamnya. Kedatangan masyarakat kota yang mewakili golongan kolonial memberikan perubahan besar bagi masyarakat pribumi.

"Tiada lama, datenglah satoe toean iang tegap badanja dan moekanja bengis bolong, tiada disoekai orang, serta ramboetnja ada amat kasar..." (Toer 2003: 380).

"Niti lantas toeroet pada toean Briot, iang berlaloeh kasar adatnja. Hatinja Niti tiada senang. Dari moelanja toean Briot masoek kerdja, Niti ada bentji pada toean itoe iang amat koerang sopan, bitjaranja kasar dan roepanja tiada boleh di perdjaja, sehingga soearanja poela membikin boekan sadja koeping pegawei pegaweinja toeli, tetapi djoega bikin roesak hati orang (Toer, 2003: 380).

Penguasaan terhadap hasil bumi, nyawa serta harga diri dari golongan pribumi merupakan bentuk pengrusakan fatal yang telah dilakukan oleh kaum kolonial. Dalam karya-karya sastra yang muncul pada masa itu, diungkapkan bahwa masyarakat dan kebudayaan sekitarnya cenderung ditempatkan sekadar sebagai latar belakang bagi petualangan dan pengalaman dari para kolonialis di negeri jajahan mereka, Indonesia. Tokoh-tokoh utama cerita tetap saja diisi oleh orang-orang Belanda sedangkan penduduk pribumi hanya tampil sebagai gundik, sebagai babu atau sebagai maling di hadapan mereka (Faruk, 2007:259). Itulah mengapa TNP karangan Kommer menjadi begitu istimewa karena didalamnya ada proses menemukan (to discover), mengenali (to identify), dan sekaligus mengakui (to recognize) keberadaan masyarakat pribumi khususnya perempuan sebagai mahluk yang otonom.

\section{Nyi Paina Sang Penyelamat}

Kata Nyi merupakan istilah umum dalam menamakan seorang gundik. Kata "nyai" atau "nyi" didapati dalam bahasa Bali, bahasa Sunda, dan bahasa Jawa dengan pengertian 'perempuan (muda), adik perempuan', dan juga dipakai sebagai istilah panggilan. Di tanah Melayu, istilah gundik atau munci lebih umum digunakan. (Hellwig, 2007: 36-37).

Nyi Paina adalah tokoh utama dalam TNP. Hal ini ditunjukkan dengan frekuensi kemunculan Paina pada cerita yang mendominasi dan tidak dapat digantikan oleh tokoh-tokoh lain yang ada. Selain itu Paina merupakan tokoh yang mengalami konflik utama dalam cerita. Berbeda dengan perempuan-perempuan pribumi yang lain, Paina terlahir sebagai gadis Jawa dengan latar belakang ekonomi yang cukup baik. Ayahnya, Niti adalah seorang juru tulis pabrik dengan gaji cukup tinggi.

"Maka Niti Admodjo sampei sekarang ini ada hidoep beroentoeng sekali. Ia sendiri dapet gadjih $\mathrm{f} 60$ seboelan, dan gajih itoe boleh di kata betoel banjak, djikaloe di piker iang pada waktoe itoe ada moesin soesah.” (Toer, 2003: 378).

Paina adalah perempuan yang memiliki kecerdasan dan daya tarik fisik luar biasa, kecantikan dan tubuhnya terawat baik. Suatu hal yang mungkin tidak dapat dilakukan oleh perempuan-perempuan pribumi lain dari golongan rendahan.

"Niti Atmodjo kadoea istri di bri oleh Toehan iang Maha koeasa doea anak prampoean iang amat tjantik dan elok parasnja, tiada ada kadoeanja di antero desa itoe. "(Toer, 2003: 378).

"Karna Nji Paina amat tjantiknja, koelitnja langsep dan ramboetnja patah 
majang, teroerai-oerai ditioep angin, maka toean Briot lantas djatoh birahi, dan tiada dapet menahan hatinja lagi, sahingga ia mengaloearken soeara seperti satoe babi roesa iang baroe mendapet makanan di oetan.” (Toer, 2003: 382).

Keelokan paras Paina menjadi daya tarik utama bagi Briot, laki-laki Belanda atasan ayahnya. Wacana kecantikan yang dimiliki Paina menandai kedudukan perempuan yang tidak dapat dilepaskan dari konstruksi budaya patriarki. Secara tidak langsung, patriarki memberi kuasa kepada laki-laki untuk memperoleh pengakuan atas feminitas perempuan. Kecantikan sebagai suatu kelebihan yang dibanggakan bagi perempuan, justru dalam kasus Paina, menjadi bumerang yang pada akhirnya mencelakainya. Perempuan, dalam hal ini diwakili oleh Paina, tidak memiliki otoritas atas tubuh dan dirinya sendiri. Tubuh dan diri perempuan menjadi objek eksploitasi yang sangat menarik bagi laki-laki. Tidak hanya dari sisi seksual, tetapi juga dari sisi stereotip perempuan sebagai mahluk yang lemah. Penguasaan terhadap tubuh dan diri perempuan menjadikan laki-laki merasa mampu untuk memperlakukan perempuan sebagaimana yang ia inginkan. Disini peran perempuan sebagai inferior sangat jelas terlihat sementara laki-laki yang berlaku superior merasa wajar memperlakukan perempuan demikian.

Posisi laki-laki superior tidak hanya terwakili oleh Briot, tetapi Niti sebagai ayah dari Paina juga mewakili posisi tersebut. Sebagai orang tua, Niti harusnya dapat melindungi anak perempuannya dari nafsu birahi Briot. Namun dalam cerita ini justru ia meminta (setengah memaksa) menyerahkan anak gadisnya untuk menjadi nyai hanya karena ketakutannya terhadap atasan dan hukuman di balik jeruji besi penjara. Secara tidak langsung, Niti sengaja menjual Paina untuk membebaskan diri dari hukuman karena kelalaiannya mengurusi keuangan di pabrik gula tempat ia bekerja. Paina sebagai tumbal atas kebebasan sang ayah. Hal ini sama dengan cerita Siti Nurbaya yang muncul dalam khasanah sastra Indonesia beberapa tahun ke depan. Hanya bedanya, Siti Nurbaya menyerah dan pasrah terhadap keinginan orang tuanya sementara Paina memiliki kekuatan untuk memberontak dan akhirnya mampu menentukan arah hidupnya sendiri.

Terdapat gambaran dalam TNP yang menunjukkan bahwa para perempuan pada masa itu (sampai masa kini juga) tumbuh di antara kekuasaan laki-laki. Ia tumbuh ditengah dunia dimana mereka dijodohkan dan harus patuh pada orang tua. Ayah maupun anggota keluarga laki-laki bahkan suami menjadi penentu utama dalam kehidupan mereka. Seorang gadis pribumi dapat diserahkan oleh orang tuanya kepada kaum kolonial untuk menjadi nyai. Berdasarkan kondisi yang berkembang pada masa itu, rata-rata perempuan yang diambil menjadi nyai bagi laki-laki kulit putih berasal dari kalangan pribumi rendahan atau mereka yang bekerja sebagai budak/pembantu di lingkungan bangsa kolonial. Kenyataan bahwa mereka dijual untuk menjadi nyai oleh ayah, suami atau saudara laki-lakinya adalah hal yang sangat menyakitkan bagi seorang perempuan. Di dalam norma masyarakat sendiri, kedudukan nyai hampir sama dengan pelacur. Lebih buruk lagi, mereka dianggap mengkhianati agama dengan hidup bersama seorang kafir, seorang Kristen.

Seorang nyai seperti halnya Nyi Paina dalam TNP boleh dikatakan tidak punya hak apapun, tidak hak atas anaknya maupun hak atas dirinya sendiri. Setiap saat dia harus siap ditinggalkan oleh majikannya tanpa bantuan dalam bentuk apapun. Di kalangan ketentaraan, seorang nyai kadang diserahkan kepada lelaki Eropa lain dengan alasan lelaki yang mengambilnya sebagai nyai itu kembali ke negara asal, telah menikah dengan perempuan kulit putih, atau bahkan telah bosan pada nyainya. Kedudukan nyai, munci atau gundik setara dengan pelacur yang harus mau menerima perlakuan apapun dari laki-lakinya. Pada kenyataannya, para 
laki-laki Eropa memperlakukan nyainya dengan sangat tidak baik, tanpa rasa hormat, bahkan seperti binatang yang hanya digunakan untuk memuaskan nafsu birahinya saja.

\begin{abstract}
“....kenyataan bahwa hubungan dengan gundik Pribumi tidak lebih dari sebuah "hubungan seksual hewani", mengingat seorang nyai "tidak dapat memberikan sentuhan jiwa sedikitpun”. .....sematamata berdasarkan naluri hewan, hubungan sehari-hari dengan mahluk perempuan yang sama sekali bodoh dan tidak berkembang-hanya demi menyalurkan kebutuhan seksual-pasti menyebabkan kemerosotan moral. ....Sekali saja seseorang pernah merasakan hidup dalam pergundikan, maka hampir selalu ada pengaruh merusak yang bisa dirasakan akibat hal tersebut.” (Baay, 2010: 84).
\end{abstract}

Namun demikian, hubungan antar gender dalam TNP ini menarik untuk dicermati. Dalam proporsi tertentu, tokoh Paina ditampilkan sama kuat dan sama pentingnya dengan tokoh laki-laki (Briot dan Niti). Teknik penokohan stereotip perempuan tak berdaya dan laki-laki perkasa sulit ditemukan dalam cerita ini. Peran Paina tak tergantikan, karena ia memiliki jatidiri sebagai perempuan yang tidak ingin diposisikan sebagai inferior. Hal itu sesuai dan sejalan dengan cita-cita feminisme yang menghendaki perempuan harus memiliki jatidiri dan berkuasa atas dirinya sendiri. Ketika ia terang-terangan menolak menjadi nyai bagi Briot dengan menyebutnya "Tjeleng" (celeng/babi rusa adalah ungkapan yang sangat kasar dalam bahasa Jawa) bahkan keberaniannya menularkan penyakit cacar sebagai salah satu cara memperdayai dan membunuh Briot adalah contoh keberanian dan kecerdikannya sebagai perempuan.

“Apa, djadi njainja tjeleng itoe?” tiada sekali-kali. Bebrapa orang melamar padakoe, tetapi koe soedah tampik dan sekarang koe hendak didjadiken boedaknja si tjeleng alas itoe.” (Toer, 2003: 389).

“....adapoen Nji Paina soedah ambil satoe kapoetoesan. Sering kali ia dapet dengar dari ajahnja dan dari orang orang lain kaloe satoe orang iang waras dateng bertjampoer oerang pada iang sakit tjatjar, penjakit itoe nanti mendjangkit dan menoelar padanja. .... Maka Nji Paina soedah tetapken atinja aken bikin mati toean Briot dengan djalan iang demikian.” (Toer 2003: 390).

Paina mengalami apa yang dinamakan subordinasi, represi serta marjinalisasi dalam lingkungannya. Melalui penolakan menjadi nyai atas tuan Briot, Paina menunjukkan keberanian dan kebangkitannya dalam menggugat dominasi sang ayah dan menentang ketidakadilan yang terjadi dalam sistem patriarkat. Meski akhirnya ia harus menyerah terhadap keputusan Niti, ayahnya untuk bersedia menjadi nyai. Tapi setidaknya keputusan itu bukan berdasarkan ketakutannya pada lakilaki, baik Briot maupun Niti, melainkan karena rasa cinta dan bakti Paina terhadap orang tua. Bagi Paina, sebagai perempuan tidaklah harus selalu tunduk pada apa yang laki-laki perintahkan. Sikap ini menunjukkan adanya aksi perlawanan terhadap sistem budaya patriarkat yang masih berkembang sampai sekarang.

“....Nji Paina tiada menjahoet satoe apa; tjoema ia mengkeretkan giginja dari marah serta liatin ajahnja dengan berdiri angkat kepalanja, iang amat bagoesnja.” (Toer 2003:389).

"Achirnja Nji Paina moelai dapet belas kasihan pada ajahnja. Kamoedian Nji Paina sendiri memoetoesken itoe perkara. Lama ia doedoek berpikir dan tiada bergerak, tiada bitjara satoe apa. Sasoedahnja, terkoenjoeng-koenjoeng ia bangoen berdiri di depan ajahnja, seperti satoe orang iang memoetoeskan perkara, seraja berkata: "Baiklah koe toeroet maoenja toean Briot aken djadi njainja." (Toer 2003: 389). 
Niti mendapat ancaman dari Briot akan dimasukkan penjara karena kelalaiannya dalam mengurusi keuangan di pabrik gula tempat ia bekerja. Hukuman itu akan dihilangkan apabila Niti mau membujuk Paina untuk menjadi nyai atau gundik bagi Briot.

“....kaloe koe soeka Nji Paina djadi njai koe, nistjaja tiada nanti terdjadi satoe apa atas dirimoe dan semoea oewang itoe kau tiada oesah bajar koembali.” (Toer, 2003: 388).

Kesediaan Paina menjadi nyai demi sang ayah adalah bentuk aksi yang menyatakan bahwa perempuan memiliki kekuatan untuk bertindak dan memutuskan sesuatu tidak hanya berdasarkan pada orientasi tubuh semata. Perempuan yang berdasarkan budaya patriarki selalu ditempatkan dalam posisi inferior ternyata mampu menyelamatkan dan melindungi laki-laki, golongan yang selama ini menyudutkannya dengan kelemahan dan keterbatasan yang perempuan miliki. Sementara itu, sang ayah yang tidak mampu berbuat banyak dan hanya bersembunyi di balik kekuatan Paina memeperlihatkan posisi superior yang selama ini mereka tempati tidak bersifat absolut dan mutlak karena dalam suatu hal tertentu golongan superior ini akhirnya tunduk pula pada kekuatan perempuan yang selalu dimarjinalkan. Dalam hal ini, Paina mampu muncul sebagai penyelamat untuk ayah dan keluarganya. Gagasan serta aksi yang dilakukan Paina menunjukkan citra positif perempuan Hindia Belanda saat itu.

\section{Nyi Paina Si Pemegang Kendali}

$\begin{array}{crr}\text { Sistem } & \text { budaya } & \text { patriarki } \\ \text { mengkondisikan } & \text { perempuan } & \text { untuk }\end{array}$ bergantung pada laki-laki. Akibatnya dalam masyarakat masih berlaku pandangan bahwa kedudukan istri bergantung pada suami, kedudukan anak perempuan tergantung pada ayah atau saudara laki-laki. Identitas anak yang lahir ditandai oleh yang membuahi, yang menurunkan bukan yang melahirkan. Dalam situasi seperti ini anak laki-laki mempunyai kekuasaan terhadap perempuan. Shulamit Firestone memandang dominasi pria sebagai bentuk penindasan kemasyarakatan dan perekonomian yang lain yang sangat utama dan bebas (Shelden, 1991: 140).

Berkaitan dengan masalah kekuasaan dan dominasi laki-laki seperti yang disebutkan di atas, melalui TNP, Kommer ingin menyampaikan pesannya. Bahwasanya pada masa kolonialpun, perempuan sudah mulai berontak dari ketertindasan dan dominasi laki-laki. Gambaran tokoh Paina adalah citraan dari wacana kebebasan dan pembebasan perempuan. Pengarang mampu mengilustrasikan sosok Paina sebagai perempuan yang pemberani, cerdas dan tidak mengenal kata menyerah. Ia bukan model perempuan cengeng, mudah hanyut dalam kesedihan serta terpuruk pada penderitaan. Paina adalah perempuan dengan kesadaran kritis yang memiliki identitas serta bebas dengan haknya. Pengalaman pahitnya menjadi nyai atas Briot menjadi pendorong untuk tetap menegakkan kepala. Penderitaan batin justru menjadi semacam motivasi positif yang memicunya untuk tampil lebih berani.

Budaya patriarki selalu berkaitan dengan dominasi dan kuasa laki-laki. Masalah ini terlihat pula pada sistem pergundikan yang merebak masa itu. Perempuan yang diambil menjadi gundik atau nyai oleh laki-laki Eropa nampak sangat tergantung pada belas kasihan majikan lelaki kulit putihnya. Namun dalam TNP pendapat itu terbantahkan karena Nyi Paina berhasil menumbangkan hegemoni laki-laki kolonial dengan cara mempertaruhkan nyawanya sendiri. Ia mengakhiri kekejaman serta pikiran bercabang-cabang dari seorang Eropa yang gila kuasa, meskipun harus merugikan dirinya sendiri. Paina berhasil melepaskan diri dari kungkungan kuasa patriarki dan menang atasnya. 
“....Penjakit tjajar itoe gampang dipindahken dari satoe ka lain orang. Maka Nji Paina soedah tetapken atinja aken bikin mati toean Briot dengan djalan iang demikian.” (Toer, 2003: 391).

“....,toean Briot kena penjakit tjajar amat sangetnja. Bagaimana djoega di obatin, toean Briot tiada djadi semboeh,...., orang dapetin toean Briot mati terletak di atas oebin di depan roemahnja dan roepanja seperti ia soedah menanggoeng sangsara besar selama sakitnja itoe.” (Toer, 2003: 391).

Paina berhasil meminjam kekuasaan penyakit cacar untuk membinasakan penguasa yang lalim. Meskipun demikian bayarannya juga cukup tinggi. Paina kehilangan kecantikannya. Paina justru dapat hidup tenang lepas dari jangkauan tangan lalim dengan wajah yang rusak/bopeng. Cerita ini berakhir dengan happyending. Chef pabrik gula diganti dan Niti mendapatkan kedudukannya yang baik kembali. Paina diambil istri oleh seorang hartawan dan hidup bahagia sampai hari tua. Cerita ini juga mengandung arti bahwa kecantikan tidak selalu membawa keberuntungan bagi pemiliknya. Fenomena Nyi Paina sebagai perempuan yang dipaksa menerima situasi sulit demi menyelamatkan keluarga dari bencana membuat ia berani memberontak terhadap kekuasaan laki-laki kulit putih dengan segala cara yang diketahuinya. Ideologi kecantikan bentukan patriarki yang mengharuskan perempuan tampil cantik dan menarik secara fisik pada akhirnya terbantahkan.Karena justru perempuan cerdas dan cerdiklah yang mampu menentukan tujuan hidup mereka. Perempuan berkuasa atas tubuh dan masa depan mereka sendiri. Bagi Paina, kecerdasan adalah kekuatan sedangkan kemolekan fisik tidak selamanya menghantarkan perempuan pada kebahagiaan.

Upaya yang dilakukan Paina bukan lagi emansipasi atau usaha mensejajarkan kedudukannya dengan laki-laki. Emansipasi, dari kata emancipatio (latin), memiliki arti persamaan hak dalam berbagai aspek kehidupan meski pada akhirnya berdasarkan kenyataan lebih mengarah pada satu objek yaitu perempuan. Emansipasi selalu dikaitkan dengan perempuan yang menuntut persamaan hak dengan laki-laki. Usaha atau aksi yang dilakukan oleh Paina tidak hanya sekedar memposisikan dirinya sama dengan laki-laki, tetapi berkaitan pula dengan persoalan seks maupun gender. Pada gilirannya, pemberontakan Paina terhadap Broit bukan sekedar usaha untuk berbuat “sebagaimana perempuan” melainkan lebih pada usaha untuk "menjadi perempuan" dengan otoritas penuh terhadap dirinya sendiri. Menurut David Graddol (Ratna, 2007:219), seseorang tidak dilahirkan dengan gender, tetapi harus mempelajari perilaku yang sesuai dengan jenis kelaminnya. Seseorang yang lahir sebagai perempuan (seks) tidak perlu dipermasalahkan sebab tidak seorangpun dapat mengubah kondisi tersebut. Sebaliknya, eksistensi seseorang menjadi perempuan tentu dapat dipermasalahkan, diterima dengan senang hati, atau sebaliknya sama sekali ditolak.

TNP berbeda dengan cerita-cerita yang berkembang pada zamannya, seperti Nyai Dasima, Sarinten, dan lain-lain. Meskipun tokoh utama yang diceritakan sama-sama perempuan, tapi dalam TNP, tokohnya tidak menyerah dengan kenikmatan harta benda yang ditawarkan laki-laki penguasa kolonial. Status "nyai" yang begitu sangat menggiurkan bagi kebanyakan perempuan pribumi, tidak menyilaukan mata Paina. Hingga ia mampu melakukan pemberontakan pada kuasa lakilaki baik Broit maupun Niti, ayahnya untuk bisa menentukan kehidupan seperti yang ia inginkan sendiri.

\section{SIMPULAN}

Dari uraian di atas dapat disimpulkan bahwa kajian feminis terhadap Tjerita Nji Paina karangan H. Kommer, terutama dari sisi perjuangan perempuan terhadap 
HUMANIKA Vol. 22 No. 2 (2015) ISSN 1412-9418

hegemoni patriarki, cukup signifikan. Dari penelusuran sederhana terhadap TNP ditemukan beberapa pesan feminisme. Sebagai perempuan, Paina menyadari keterpinggirannya, namun tanpa menyerah sedikitpun ia berjuang untuk memperoleh kebebasan yang didambakan. Cerita ini tidak memberikan celah pada pembaca untuk berbelas kasih, meratapi atau bahkan menertawakan ketidak berdayaan perempuan.

Paina adalah gambaran yang mewakili perempuan Hindia Belanda pada masanya.
Melalui perannya sebagai nyai, ia mampu menawarkan ruang untuk merefleksi, merenung, melihat dan membaca ulang teks serta narasi tradisi yang menempatkan sekelompok orang sebagai bagian inferior dari kelompok yang lain. Namun dengan keberanian dan kecerdasan yang dimiliki, ia mampu menumbangkan hegemoni superior dalam sistem budaya patriarki.

\section{DAFTAR PUSTAKA}

Baay, Reggie. 2009. Nyai dan Pergundikan di Hindia Belanda. Jakarta: Komunitas Bambu.

Djajanegara, Soenarjati. 2000. Kritik Sastra Feminis: Sebuah Pengantar. Jakarta: Gramedia

Faruk. 2007. Belenggu Pasca-Kolonial: Hegemoni dan Resistensi dalam Sastra Indonesia. Yogyakarta: Pustaka Pelajar.

Hellwig, Tineke. 2007. Citra Kaum Perempuan di Hindia Belanda. Terjemahan. Mien Joebhaar. Jakarta: yayasan Obor Indonesia.

Ratna, Nyoman Kutha. 2007. Sastra dan Cultural Studies: Representasi Fakta dan Fiksi. Yogyakarta: Pustaka Pelajar.

Selden, Raman. 1994. Panduan Pembaca Teori Sastra Masa Kini. Diterjemahkan oleh Rahmat Djoko Pradopo dan Imran $\mathrm{T}$ Abdullah. Yogyakarta: Gama Press.

Sumardjo, Jakob. 2004. Kesusastraan Melayu Rendah: Masa Awal. Yogyakarta: Galang Press.

Toer, Pramoedya Ananta. 2003. Tempo Doeloe: Antologi Sastra PraIndonesia. Jakarta: Lentera Dipantara. 